\title{
Evaluation of D-dimer and lactate dehydrogenase plasma levels in patients with relapsed acute leukemia
}

\author{
WANGQIANG HU, XIAOXIA WANG and RONGRONG YANG \\ Department of Laboratory Medicine, The First Affiliated Hospital of Wenzhou Medical University, \\ Wenzhou, Zhejiang 325000, P.R. China
}

Received April 1, 2015; Accepted May 16, 2016

DOI: $10.3892 / \mathrm{ol} .2016 .4657$

\begin{abstract}
Despite the outstanding advances made over the past decade regarding our knowledge of acute leukemia (AL), relapsed AL remains to be associated with a dismal prognosis. A better understanding of AL relapse and monitoring of the D-dimer and lactate dehydrogenase (LDH) plasma levels following chemotherapy may aid clinicians in determining whether relapse may occur in the subsequent phases of the disease. The present study evaluated D-dimer and LDH levels in 204 patients with relapsed AL. Data were collected at the initial onset of AL, at complete remission (CR) and in patients with relapsed AL. D-dimer plasma levels were significantly increased in patients with initial AL and in patients with relapsed $\mathrm{AL}(\mathrm{P}=0.005$ and $\mathrm{P}=0.007$, respectively) but not in those with CR. LDH levels were significantly increased in AL patients at the initial onset of disease and at relapse compared with patients achieving CR, irrespective of cell type. Plasma prothrombin time, activated partial thromboplastin time and fibrinogen levels were not significantly different across patients (with the exception of acute promyelocytic leukemia patients) at the initial onset, relapsed AL or CR. Routine hematological parameters (white blood cell count, hemoglobin, platelet count) were significantly different at the initial onset of $\mathrm{AL}$ ( $\mathrm{P}=0.002, \mathrm{P}<0.001$ and $\mathrm{P}=0.001$, respectively) and during relapsed $\mathrm{AL}(\mathrm{P}=0.009, \mathrm{P}=0.003$ and $\mathrm{P}<0.001$, respectively) compared with patients achieving $\mathrm{CR}$, suggesting an association between D-dimer, LDH and relapsed AL. These results also indicate that determination of D-dimer and LDH levels may be useful for predicting the probability of relapse during chemotherapy, but should also be combined with routine hematological parameters.
\end{abstract}

Correspondence to: Dr Wangqiang Hu, Department of Laboratory Medicine, The First Affiliated Hospital of Wenzhou Medical University, 2 Fuxue Alley, Wenzhou, Zhejiang 325000, P.R. China E-mail: hwqwz83@163.com

Key words: D-dimer, lactate dehydrogenase, acute leukemia, relapse

\section{Introduction}

Acute leukemia (AL) is a clonal disease that progressively produces novel sub-clones, which exhibit altered phenotypic and cytogenetic traits. AL is divided into acute lymphoblastic leukemia (ALL) and acute myeloid leukemia (AML). AML is the most common type of leukemia in adults. Acute promyelocytic leukemia (APL) is a distinct subtype of AML characterized by coagulopathy and signs of disseminated intravascular coagulation $(1,2)$. It is not known whether coagulation results are associated with AL except in APL. Therefore, the comparison of certain clinical parameters of AL patients, including activated partial thromboplastin time (aPTT), prothrombin time (PT), D-dimer and fibrinogen (FIB) should be eliminated due to interference from the APL cohort. Despite high sensitivity to standard chemotherapy, which leads to increased rate of complete remission (CR) in the two subtypes of $\mathrm{AL}, \sim 1 / 3$ of AL patients subsequently relapse (3-6). AL relapse following standard chemotherapy remains a significant therapeutic challenge (7-10). AL continues to have a low survival rate compared to other cancers (11). Disease-free survival rates are $5-15 \%$ in older adults and $25-40 \%$ in younger patients (12).

Metabolic changes occur as part of oncogenesis and tumor progression. A better understanding of AL relapse and the careful monitoring of clinical parameters following chemotherapy may aid clinicians in determining the best treatment options on an individual patient basis. As a result of local activation of intravascular coagulation at the onset of some forms of malignancy $(13,14)$, the fibrinolytic marker D-dimer increases and accumulates (14). LDH exists in numerous cell systems and, subsequent to tissue or cell damage, serum LDH levels may increase (15). Although it is generally understood that there is a poor outcome for adults with AL that develop bone marrow relapse (16) and various risk factors predicting outcome are continuously analyzed, there are few studies concerning LDH and D-dimer in these types of patients. The present study was performed to determine whether D-dimer and LDH levels during treatment are associated with relapse in patients with AL.

\section{Materials and methods}

Patients. The present study evaluated data from 204 patients that were newly diagnosed with AL at the The First Affiliated 
Hospital of Wenzhou Medical University (Wenzhou, China) between February 2010 and October 2014, several of whom relapsed. At the initial onset, 204 patients were treated uniformly for AML or ALL. AL was classified according to the FAB criteria (17). In total there were 40 ALL patients and 164 AML patients (M1, 44; M2, 26; M3, 32; M4, 36; M5, 20; M6, 6). AML patients only were treated with daunorubicin (45 $\mathrm{mg} / \mathrm{m}^{2}$ per day on days $\left.1-3\right)$ and cytarabine $\left(150 \mathrm{mg} / \mathrm{m}^{2}\right.$ per day for 7 days) according to the 3 plus 7 regimen. APL patients were treated based on an all-trans retinoic acid $\left(20 \mathrm{mg} / \mathrm{m}^{2}\right.$ per day on days 1-15) plus anthracycline (idarubicin; $8 \mathrm{mg} / \mathrm{m}^{2}$ per day on days 1-3) protocol. The induction chemotherapy in ALL patients included vincristine ( $2 \mathrm{mg}$ per day on days $1,8,15$ and 22) and daunorubicin ( $40 \mathrm{mg} / \mathrm{m}^{2}$ per day on days $\left.1-3\right)$, prednisone $] 1 \mathrm{mg} / \mathrm{kg}$ per day on days 1-14 and 15-28 (2/3 dose)] and L-asparaginase $\left(6,000 \mathrm{IU} / \mathrm{m}^{2}\right.$ per day on days $11,14,17,20,23$ and 26). The AL patients were free from any systemic, cardiovascular or inflammatory illnesses. The Ethics Committee at The First Affiliated Hospital of Wenzhou Medical University approved the present study. Written informed consent was obtained from the patients.

Blood collection. Blood samples were taken from the antecubual vein and placed in plastic tubes containing 3.8\% trisodium citrate $(9$ volumes of blood and 1 volume of $0.1 \mathrm{M}$ trisodium citrate) or ethylenediaminetetraacetic acid (EDTA) $\mathrm{K}_{2}$ anticoagulant. For plasma separation, blood was centrifuged at $2,500 \mathrm{x}$ g for $15 \mathrm{~min}$ at $4^{\circ} \mathrm{C}$; blood samples were obtained prior to the initiation of any treatment for AL. The present study adhered to the tenets of the Declaration of Helsinki.

Data collection. Blood counts were performed using an XE 2100 Sysmex $^{\mathrm{TM}}$ automated hematology analyzer (Sysmex, Kobe, Japan). aPTT, PT, D-dimer and FIB were measured using a STAGO Coagulation analyzer (Diagnostica Stago, Asnières, France). The STA ${ }^{\circledR}$-Liatest ${ }^{\circledR}$ D-Di kit (Diagnostica Stago) is intended for use with analyzers of the STA ${ }^{\circledR}$ line suitable with these reagents for the quantitative determination of D-dimer in plasma by immuno-turbidimetric method. The STA ${ }^{\circledR}$-fibrinogen kit (Diagnostica Stago) is intended for use with STA- ${ }^{\circledR}$ analyzers for the quantitative determination of FIB levels in plasma using the clotting method of Clauss. The STA ${ }^{\circledR}$-néoplastine Cl Plus and STA ${ }^{\circledR}$-APTT kits (Diagnostica Stago) are intended for use with STA- $\mathrm{R}^{\circledR}$ analyzers for the determination of PT and aPTT in plasma by the clotting method, respectively. Lactate dehydrogenase (LDH) plasma levels were measured using the LDH substrates method (Beckman Coulter Experiment System Co., Ltd., Suzhou, China). Markers were compared against normal ranges, which were as follows: White blood cell (WBC) count, 3.5-9.5 $\times 10^{9} / 1$; platelet (PLT) count, 125.0-350.0x109/1; hemoglobin ( $\mathrm{Hb}$ ), 115.0-175.0 g/l; PT, 11.6-14.9 sec; aPTT, 29.0-43.0 sec; FIB, 2.0-4.0 g/l; D-dimer, 0.0-0.5 mg/l; and LDH, 0.0-247.0 units (U)/1. The laboratory data were collected promptly at the initial onset of AL, CR and in patients with relapsed AL.

Response evaluation. The diagnostics were comprised of cytomorphology, cytochemistry, cytogenetics, molecular genetics and immunophenotyping of bone marrow or peripheral blood. Bone marrow aspirate smears were applied to assess the therapeutic effect of AL. The morphological diagnosis and classification were performed according to the WHO 2008 diagnostic criteria (18).

Statistical analysis. The results were graphed using line charts depicting medians and range. The data were analyzed using the Wilcoxon matched pairs test. Spearman's rank correlation coefficient was used to analyze correlations between serum D-dimer or LDH level and selected blood routine parameters. P-values of $<0.05$ were considered to indicate a statistically significant difference. Data were analyzed using SPSS version 13.0 for Windows (SPSS, Chicago, IL, USA).

\section{Results}

Clinical parameters of AL patients at various stages of disease. Laboratory data in patients with initial onset, CR and relapsed $\mathrm{AL}$ are shown in Table I. The WBC count was significantly different at the initial onset of $\mathrm{AL}(\mathrm{P}=0.002)$ and during relapsed $\mathrm{AL}$, compared with patients in the $\mathrm{CR}$ group $(\mathrm{P}=0.009)$. Hb levels $(\mathrm{P}<0.001$ and $\mathrm{P}=0.003)$ and PLT counts $(\mathrm{P}=0.001$ and $\mathrm{P}<0.001)$ were significantly reduced in the initial onset and relapsed $\mathrm{AL}$ groups. compared with the $\mathrm{CR}$ group. $\mathrm{D}$-dimer $(\mathrm{P}=0.005$ and $\mathrm{P}=0.007)$ and $\mathrm{LDH}$ levels $(\mathrm{P}=0.007$ and $\mathrm{P}=0.008)$ were also significantly increased in the two groups compared with the $\mathrm{CR}$ group (Figs. 1 and 2). In addition, these levels were significantly different across the two groups compared with $\mathrm{AL}$ in $\mathrm{CR}$, regardless of whether APL patients were included. Plasma PT and FIB levels were significantly $(\mathrm{P}=0.020)$ increased in the initial onset and relapsed AL groups compared with patients achieving CR. Plasma FIB levels were significantly decreased in the initial onset $(\mathrm{P}=0.008)$ and relapsed $\mathrm{AL}$ groups $(\mathrm{P}=0.009)$ compared with patients achieving CR. Plasma aPTT levels were not significantly different between patients with initial onset or relapsed $\mathrm{AL}$ and $\mathrm{AL}$ in $\mathrm{CR}$. When coagulation data results were eliminated in patients with APL, plasma levels of aPTT were elevated, but plasma PT, aPTT and FIB levels were not significantly different between patients with relapsed AL and $\mathrm{AL}$ in $\mathrm{CR}$.

Plasma levels of D-dimer and LDH levels in all subtypes of $A L$ at various stages of disease. In the AML-M1 group (Table II), LDH $(\mathrm{P}=0.030)$ and $\mathrm{D}$-dimer $(\mathrm{P}=0.020)$ plasma levels were significantly increased at the initial onset of $A L$ compared with during CR. The plasma levels of D-dimer and LDH were significantly increased in the relapsed group compared with the $C R$ group $(\mathrm{P}=0.010$ and $\mathrm{P}=0.020$, respectively), which were higher during relapse compared with at initial onset of AL. In the AML-M2 group, $\mathrm{LDH}(\mathrm{P}=0.008$ and $\mathrm{P}=0.010)$ and $\mathrm{D}$-dimer $(\mathrm{P}=0.008$ and $\mathrm{P}=0.007)$ plasma levels were significantly increased in the initial onset and relapsed groups compared with CR; LDH plasma levels were increased in patients with initial onset of M2 compared with relapsed patients. The highest values of D-dimer were observed in AML-M3 patients. D-dimer plasma levels were significantly increased at initial onset of APL compared with during CR, and significantly increased during relapse compared with CR. Plasma LDH levels were significantly greater in patients at the initial onset and in patients with relapsed AL compared with patients achieving $\mathrm{CR}(\mathrm{P}=0.009$ and $\mathrm{P}=0.007$, respectively). 
Table I. Blood routine and coagulation measurements in patients at various stages of AL.

\begin{tabular}{|c|c|c|c|c|c|c|}
\hline \multirow[b]{2}{*}{ Characteristics } & \multicolumn{3}{|c|}{ AL disease including APL, median (range) } & \multicolumn{3}{|c|}{ AL disease except for APL, median (range) } \\
\hline & Initial onset & CR & Relapse & Initial onset & $\mathrm{CR}$ & Relapse \\
\hline $\mathrm{WBC}, \times 10^{9} / 1$ & $\begin{array}{c}11.6 \\
(0.1-658.4)^{\mathrm{a}}\end{array}$ & $\begin{array}{c}4.8 \\
(2.1-13.2)\end{array}$ & $\begin{array}{c}5.8 \\
(0.1-328.0)^{\mathrm{c}}\end{array}$ & $\begin{array}{c}21.9 \\
(1.1-200.0)^{\mathrm{a}}\end{array}$ & $\begin{array}{c}4.2 \\
(2.4-10.3)\end{array}$ & $\begin{array}{c}10.6 \\
(0.1-254.4)^{\mathrm{c}}\end{array}$ \\
\hline $\mathrm{Hb}, \mathrm{g} / \mathrm{l}$ & $\begin{array}{c}79.0 \\
(34.0-149.0)^{\mathrm{a}}\end{array}$ & $\begin{array}{c}105.0 \\
(64.0-155.0)\end{array}$ & $\begin{array}{c}92.0 \\
(45.0-148.0)^{\mathrm{c}}\end{array}$ & $\begin{array}{c}80.0 \\
(34.0-148.0)^{\mathrm{a}}\end{array}$ & $\begin{array}{c}101.0 \\
(64.0-140.0)\end{array}$ & $\begin{array}{c}90.0 \\
(45.0-145.0)^{\mathrm{c}}\end{array}$ \\
\hline PLT, $x 10^{9} / 1$ & $\begin{array}{c}30.0 \\
(5.0-235.0)^{\mathrm{a}}\end{array}$ & $\begin{array}{c}180.0 \\
(6.0-460.0)\end{array}$ & $\begin{array}{c}32.0 \\
(4.0-167.0)^{\mathrm{c}}\end{array}$ & $\begin{array}{c}41.0 \\
(6.0-235.0)^{\mathrm{a}}\end{array}$ & $\begin{array}{c}143.0 \\
(21.0-462.0)\end{array}$ & $\begin{array}{c}32.0 \\
(6.0-167.0)^{\mathrm{c}}\end{array}$ \\
\hline PT, sec & $\begin{array}{c}15.6 \\
(12.5-33.6)^{b}\end{array}$ & $\begin{array}{c}13.7 \\
(11.7-18.1)\end{array}$ & $\begin{array}{c}14.6 \\
(11.9-22.8)^{\mathrm{d}}\end{array}$ & $\begin{array}{c}14.2 \\
(12.5-21.6)\end{array}$ & $\begin{array}{c}13.3 \\
(11.7-18.1)\end{array}$ & $\begin{array}{c}14.1 \\
(12.1-21.4)\end{array}$ \\
\hline aPTT, sec & $\begin{array}{c}38.8 \\
(26.6-75.5)\end{array}$ & $\begin{array}{c}38.8 \\
(29.1-58.8)\end{array}$ & $\begin{array}{c}39.8 \\
(25.9-59.6)\end{array}$ & $\begin{array}{c}38.1 \\
(30.0-75.5)\end{array}$ & $\begin{array}{c}38.4 \\
(29.4-57.8)\end{array}$ & $\begin{array}{c}39.3 \\
(25.9-55.5)\end{array}$ \\
\hline FIB, g/l & $\begin{array}{c}3.5 \\
(0.2-9.1)^{\mathrm{a}}\end{array}$ & $\begin{array}{c}3.7 \\
(0.6-8.5)\end{array}$ & $\begin{array}{c}2.9 \\
(0.8-8.4)^{\mathrm{c}}\end{array}$ & $\begin{array}{c}3.77 \\
(0.8-8.5)\end{array}$ & $\begin{array}{c}3.4 \\
(0.6-8.5)\end{array}$ & $\begin{array}{c}3.3 \\
(1.26-7.39)\end{array}$ \\
\hline D-dimer, mg/l & $\begin{array}{c}4.2 \\
(0.5-47.0)^{\mathrm{a}}\end{array}$ & $\begin{array}{c}1.2 \\
(0.1-7.2)\end{array}$ & $\begin{array}{c}2.7 \\
(0.3-40.0)^{\mathrm{c}}\end{array}$ & $\begin{array}{c}2.2 \\
(0.5-10.4)^{\mathrm{a}}\end{array}$ & $\begin{array}{c}0.6 \\
(0.1-1.6)\end{array}$ & $\begin{array}{c}1.6 \\
(0.3-17.4)^{\mathrm{c}}\end{array}$ \\
\hline LDH, units/l & $\begin{array}{c}385.0 \\
(140.0-2,894.0)^{\mathrm{a}}\end{array}$ & $\begin{array}{c}198.0 \\
(29.0-405.0)\end{array}$ & $\begin{array}{c}335.0 \\
(88.0-4,919.0)^{\mathrm{c}}\end{array}$ & $\begin{array}{c}395.0 \\
(156.0-2,405.0)^{\mathrm{a}}\end{array}$ & $\begin{array}{c}173.0 \\
(69.0-293.0)\end{array}$ & $\begin{array}{c}376.0 \\
(88.0-4,919.0)^{\mathrm{c}}\end{array}$ \\
\hline
\end{tabular}

${ }^{\mathrm{a}} \mathrm{P}<0.01,{ }^{\mathrm{b}} \mathrm{P}<0.05$; significant difference between initial onset $\mathrm{AL}$ patients and $\mathrm{CR} .{ }^{\mathrm{c}} \mathrm{P}<0.01,{ }^{\mathrm{d}} \mathrm{P}<0.05$; significant difference between relapse patients and CR. AL, acute leukemia; APL, acute promyelocytic leukemia; WBC, white blood cell; Hb, hemoglobin; PLT, platelet; PT, prothrombin time; aPTT, activated partial thromboplastin time; FIB, fibrinogen; LDH, lactate dehydrogenase.

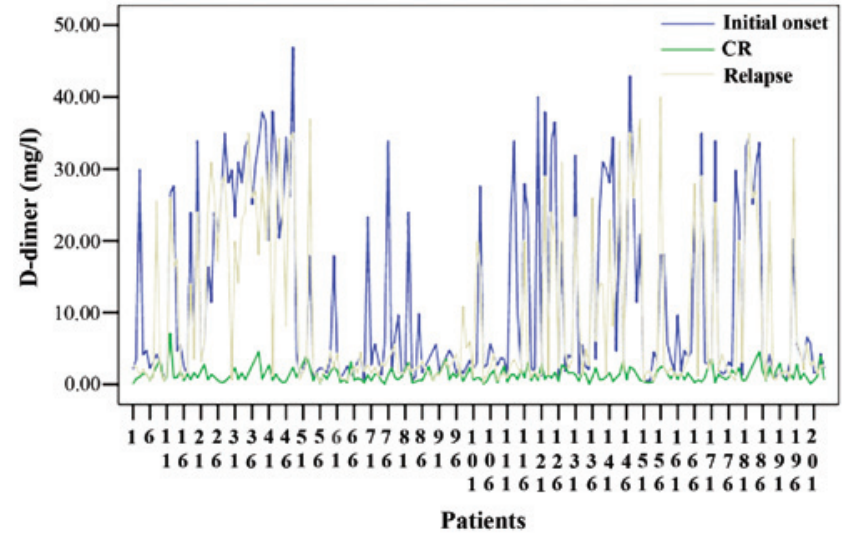

Figure 1. A paired analysis line chart demonstrating significantly elevated D-dimer levels in patients with relapsed acute leukemia compared with the same patients with CR. CR, complete remission.

In the AML-M4 patients group, D-dimer plasma levels were significantly increased in patients with initial onset and patients with relapsed $\mathrm{AL}(\mathrm{P}=0.010$ and $\mathrm{P}=0.030$, respectively), but not with CR. LDH levels in AML-M4 patients were significantly increased at initial onset and in relapsed $\mathrm{AL}$ compared with at CR. In the AML-M5 patients group, $\mathrm{D}$-dimer $(\mathrm{P}=0.030$ and $\mathrm{P}=0.040)$ and $\mathrm{LDH}(\mathrm{P}=0.020$ and $\mathrm{P}=0.040)$ plasma levels significantly increased in the relapsed group and initial onset of disease compared with the CR group. In the AML-M6 patient group, D-dimer plasma levels increased during relapsed $\mathrm{AL}(\mathrm{P}=0.030)$, but not at initial onset of AL compared with patients with CR. Plasma LDH levels were significantly greater in patients with initial onset and relapsed AL compared with

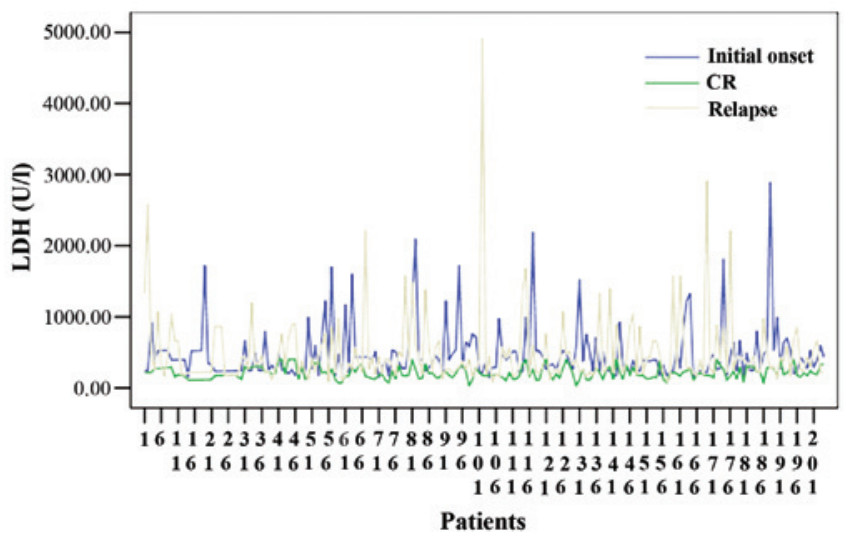

Figure 2. A paired analysis line chart demonstrating significantly elevated LDH levels in patients with relapsed acute leukemia compared with the same patients with CR. CR, complete remission.

CR $(\mathrm{P}=0.030$ and $\mathrm{P}=0.020$, respectively). In the ALL patient group, D-dimer plasma levels were significantly increased in the initial onset and relapsed groups compared with the CR group, but were higher at the initial onset of ALL compared with during relapse. LDH plasma levels significantly increased at initial onset and during relapse compared with patients achieving $\mathrm{CR}(\mathrm{P}=0.005$ and $\mathrm{P}=0.002$, respectively).

Serum LDH levels were elevated in the majority of $\mathrm{AL}$ patients following initial diagnosis and in relapsed patients; however, there does not appear to be a correlation between increased $\mathrm{LDH}$ levels and blood routine parameters in $\mathrm{AL}$ patients. Increased D-dimer concentrations demonstrated no correlation with any blood routine parameters in AL patients. 
Table II. Clinical parameters of patients with various stages of AL subtypes.

\begin{tabular}{|c|c|c|c|c|c|c|c|}
\hline \multirow[b]{2}{*}{ Subtype } & \multirow[b]{2}{*}{ No. of cases } & \multicolumn{3}{|c|}{ D-dimer (median, range) } & \multicolumn{3}{|c|}{ LDH (median, range) } \\
\hline & & Initial onset & $\mathrm{CR}$ & Relapse & Initial onset & $\mathrm{CR}$ & Relapse \\
\hline M1 & 44 & $\begin{array}{c}1.8 \\
(0.7-18.0)^{\mathrm{b}}\end{array}$ & $\begin{array}{c}1.0 \\
(0.2-3.0)\end{array}$ & $\begin{array}{c}1.9 \\
(0.9-40.0)^{\mathrm{d}}\end{array}$ & $\begin{array}{c}359.0 \\
(156.0-704.0)^{\mathrm{b}}\end{array}$ & $\begin{array}{c}166.0 \\
(77.0-400.0)\end{array}$ & $\begin{array}{c}424.0 \\
(100.0-588.0)^{\mathrm{d}}\end{array}$ \\
\hline M2 & 26 & $\begin{array}{c}2.6 \\
(0.9-4.2)^{\mathrm{a}}\end{array}$ & $\begin{array}{c}1.8 \\
(0.3-3.6)\end{array}$ & $\begin{array}{c}3.2 \\
(0.9-6.0)^{\mathrm{c}}\end{array}$ & $\begin{array}{c}432.0 \\
(217.0-760.0)^{\mathrm{a}}\end{array}$ & $\begin{array}{c}176.0 \\
(69.0-334.0)\end{array}$ & $\begin{array}{c}260.0 \\
(163.0-984.0)^{\mathrm{d}}\end{array}$ \\
\hline M3 & 32 & $\begin{array}{c}29.0 \\
(1.3-47.0)^{\mathrm{a}}\end{array}$ & $\begin{array}{c}1.0 \\
(0.3-7.2)\end{array}$ & $\begin{array}{c}24 \\
(0.5-37.0)^{\mathrm{c}}\end{array}$ & $\begin{array}{c}253.0 \\
(180.0-929.0)^{\mathrm{a}}\end{array}$ & $\begin{array}{c}200.0 \\
(140.0-405.0)\end{array}$ & $\begin{array}{c}297.0 \\
(110.0-1,200.0)^{c}\end{array}$ \\
\hline M4 & 36 & $\begin{array}{c}3.3 \\
(1.2-34.0)^{\mathrm{b}}\end{array}$ & $\begin{array}{c}1.4 \\
(0.1-5.3)\end{array}$ & $\begin{array}{c}2.4 \\
(1.0-13.5)^{\mathrm{d}}\end{array}$ & $\begin{array}{c}484.0 \\
(140.0-2,405.0)^{\mathrm{b}}\end{array}$ & $\begin{array}{c}192.0 \\
(29.0-334.0)\end{array}$ & $\begin{array}{c}363.0 \\
(167.0-2,584.0)^{\mathrm{c}}\end{array}$ \\
\hline M5 & 20 & $\begin{array}{c}2.3 \\
(1.0-3.7)^{\mathrm{b}}\end{array}$ & $\begin{array}{c}0.6 \\
(0.1-1.9)\end{array}$ & $\begin{array}{c}1.7 \\
(0.3-3.4)^{\mathrm{d}}\end{array}$ & $\begin{array}{c}419.0 \\
(162.0-1,725.0)^{\mathrm{b}}\end{array}$ & $\begin{array}{c}154.0 \\
(76.0-287.0)\end{array}$ & $\begin{array}{c}263.0 \\
(88.0-569.0)^{\mathrm{d}}\end{array}$ \\
\hline M6 & 6 & $\begin{array}{c}0.5 \\
(0.5-1.0)\end{array}$ & $\begin{array}{c}0.4 \\
(0.2-1.1)\end{array}$ & $\begin{array}{c}1.6 \\
(1.5-1.8)^{\mathrm{d}}\end{array}$ & $\begin{array}{c}379.0 \\
(240.0-644.0)^{\mathrm{b}}\end{array}$ & $\begin{array}{c}148.0 \\
(128.0-187.0)\end{array}$ & $\begin{array}{c}409.0 \\
(376.0-424.0)^{\mathrm{d}}\end{array}$ \\
\hline ALL & 40 & $\begin{array}{c}4.1 \\
(0.7-24.0)^{\mathrm{a}}\end{array}$ & $\begin{array}{c}1.2 \\
(0.1-3.5)\end{array}$ & $\begin{array}{c}2.1 \\
(0.5-25.6)^{d}\end{array}$ & $\begin{array}{c}496.0 \\
(214.0-2,894.0)^{\mathrm{a}}\end{array}$ & $\begin{array}{c}255.0 \\
(114.0-400.0)\end{array}$ & $\begin{array}{c}630.0 \\
(119.0-4,919.0)^{c}\end{array}$ \\
\hline
\end{tabular}

${ }^{a} \mathrm{P}<0.01,{ }^{b} \mathrm{P}<0.05$; significant difference between initial onset $\mathrm{AL}$ patients and $\mathrm{CR} .{ }^{\mathrm{c}} \mathrm{P}<0.01,{ }^{\mathrm{d}} \mathrm{P}<0.05$; significant difference between relapse patients and CR. AL, acute leukemia; LDH, lactate dehydrogenase; CR, complete remission; ALL, acute lymphocytic leukemia.

\section{Discussion}

Despite the outstanding advances made over the past decade regarding our knowledge of AL, AL relapse following routine conventional-dose chemotherapy remains to be associated with a dismal prognosis $(3-6,8,10)$. D-dimers are a sensitive measure of endogenous fibrinolysis and are used to screen for deep vein thrombosis (19-24). Elevated LDH levels have frequently been observed in animal and human malignancies $(15,25,26)$; in addition, there appears to be a strong correlation between disease activity and tumor mass (27). The association, pathogenesis and significance of D-dimers and LDH levels with relapse within the subtypes of AML and ALL are currently unknown. A clear understanding of the associations between these parameters and relapsed AL patients requires additional research.

Coagulation disorders are frequently observed in APL and can also occur in other AL subtypes (28-30). The pathogenic mechanism underlying the blood coagulation disorder in these patients is complex. The levels of D-dimer complex generally reflect the functional state of the clotting and fibrinolysis systems and support the existence of a hypercoagulable state $(19,20,31,32)$.

In the present study, during the initiation of $\mathrm{AL}, \mathrm{PT}$ was found to be significantly prolonged $(\mathrm{P}=0.020)$, plasma levels of FIB were significantly decreased $(\mathrm{P}=0.009)$, the levels of D-dimer were elevated in all subtypes of AML and ALL, and the highest levels of D-dimer were found in AML-M3 (Tables I and II); however, there was no significant difference in aPTT between patients with initial onset and those with CR, or between relapse and CR. When coagulation data results were eliminated in patients with APL, plasma PT, aPTT and FIB levels were not significantly increased at the initial onset of AL or during AL relapse compared to patients with CR.
The results of the present study indicate that the determination of D-dimer levels may be useful for predicting the probability of relapse during chemotherapy, as the PT, aPTT and FIB tests were not reliable markers of AL relapse.

Increased D-dimer levels at initial onset, which further increased during relapse, strongly suggest a hypercoagulable state, with secondary activation of fibrinolysis in the majority of patients $(33,34)$. Activation of coagulation and secondary activation of fibrinolysis are likely to occur continuously and simultaneously throughout circulation $(20,24,34)$. The activation of coagulation is most likely associated with the leukemic cells circulating in the blood, which may contain procoagulants, and the content of these substances depends on the leukemia subtype $(35,36)$. These substances may be released into the blood from disintegrating cells during relapse.

Tanaka et al (35) confirmed that the development of disseminated intravascular coagulation in patients with $\mathrm{AL}$ prior to chemotherapy is associated with the presence of tissue factor (TF) on the surface of the leukemic cells. TF is a major procoagulant that initiates blood coagulation in vivo and is the membrane protein receptor for factor VII. The resulting factor VIIa activates factors IX and X, leading to thrombin generation and fibrin formation $(35,37,38)$. The TF gene is expressed in cells from patients with AL.

In the present study, cells from AML patients expressed particularly high VII activity; these levels become essentially undetectable when patients are in CR. Other procoagulant mediators, including tumor necrosis factor $\alpha(39,40)$, cysteine proteinase (41), interferon- $\gamma$ (40), asinterleukin-1 (42) and vascular permeability factor (43), are regarded as indirect procoagulants as they initiate coagulation by inducing $\mathrm{TF}$ in endothelial cells and monocytes (44). In addition, natural apoptosis may contribute to thrombogenesis in $\mathrm{AL}$ via the release of microparticles from the damaged leukemic 
cells (35). Coagulation disorders may also occur due to leukemia-associated complications, including infection or organic impairment (45).

Notably, for patients that achieved CR following the induction of chemotherapy, D-dimer levels did not return to a normal value. The increased D-dimer levels during CR following chemotherapy treatment suggest a hypercoagulable state with secondary activation of fibrinolysis. Velasco et al (46). Observed an increase in the D-dimer level during treatment in patients with AML. In the present study, the results showed that the LDH levels were moderately elevated in the majority of AL patients with the exception of the CR phase, irrespective of cell type. Significantly elevated levels were recorded in the majority of patients with ALL but there was no significant difference in serum LDH levels between AML and ALL patients during relapse; in addition, no significant difference was found at initial onset of AL and during relapse.

In patients with increased levels of $\mathrm{LDH}$ at diagnosis, $\mathrm{AL}$ relapse was not found to lead to significant elevation. $\mathrm{LDH}$ activity reflects increased glycolysis in the cytoplasm of malignant cells accompanied by a high metabolic rate $(15,25)$. The increase of serum LDH activity may be due to thrombotic microangiopathy, intravascular hemolysis or tumor lysis $(25,26)$. Certain values from the ALL patients were remarkably high (Table II), and the majority of these patients had a high WBC counts during relapse. This phenomenon is likely due to the correlation between LDH levels and the number of circulating ALL blasts during relapse (47). Cumulative evidence indicates that serum LDH levels can be a good and reliable prognostic marker of ALL patients (48-50), suggesting an association between LDH levels and relapse.

Although D-dimer and LDH levels have been shown to be elevated in all subtypes of AML and ALL, none of these parameters provide diagnostic specificity. In the present study, a significant change in routine hematological parameters was indicated in patients with relapsed AL, which is consistent with previous findings $(51,52)$. The most important and most common associated risk factors for the hematological relapse of AL are thrombocytopenia, leukocyte count and lower hemoglobin, which is associated with the proliferating leukemic clone $(53,54)$. Ambulatory monitoring of D-dimer, LDH, and routine hematological parameters are recommended for the assessment of relapse in AL patients.

In conclusion, the present study demonstrated that D-dimer and LDH plasma levels were significantly increased at initial onset and during relapse in $\mathrm{AL}$ patients compared to those with CR. D-dimer and LDH levels may be useful for predicting AL relapse; therefore, the present study recommends that monitoring D-dimer and LDH for the assessment of AL relapse.

\section{Acknowledgements}

The authors gratefully acknowledge the patients for participating in the present study, and thank Dr Xiao Bo Nie for the critical reading of this manuscript.

\section{References}

1. Deschler B and Lübbert M: Acute myeloid leukemia: Epidemiology and etiology. Cancer 107: 2099-2107, 2006.
2. Lo-Coco F, Ammatuna E, Montesinos P, and Sanz MA: Acute promyelocytic leukemia: Recent advances in diagnosis and management. Semin Oncol 35: 401-409, 2008.

3. Inagaki J, Fukano R, Noguchi M, Kurauchi K, Tanioka S and Okamura J: Hematopoietic stem cell transplantation following unsuccessful salvage treatment for relapsed acute lymphoblastic leukemia in children. Pediatr Blood Cancer 62: 674-679, 2015.

4. Cui L, Gao C, Zhang RD, Jiao Y, Li WJ, Zhao XX, Liu SG, Yue ZX, Zheng HY, Deng GR, et al: Low expressions of ARS2 and CASP8AP2 predict relapse and poor prognosis in pediatric acute lymphoblastic leukemia patients treated on China CCLG-ALL 2008 protocol. Leuk Res 39: 115-123, 2015.

5. Arakawa Y, Koh K, Aoki T, Kubota Y, Oyama R, Mori M, Hayashi $M$ and Hanada R: Clofarabine-based combination chemotherapy for relapse and refractory childhood acute lymphoblastic leukemia. Rinsho Ketsueki 55: 2316-2319, 2014.

6. Bruedigam C, Bagger FO, Heidel FH, Paine Kuhn C, Guignes S, Song A, Austin R, Vu T, Lee E, Riyat S, et al: Telomerase inhibition effectively targets mouse and human AML stem cells and delays relapse following chemotherapy. Cell Stem Cell 15: 775-790, 2014.

7. Ilyas AM, Ahmad S, Faheem M, Naseer MI, Kumosani TA, Al-Qahtani MH, Gari M and Ahmed F: Next generation sequencing of acute myeloid leukemia: Influencing prognosis. BMC Genomics 16 (Suppl 1): S5, 2015.

8. Itzykson R, Thépot S, Berthon C, Delaunay J, Bouscary D, Cluzeau T, Turlure P, Prébet T, Dartigeas C, Marolleau JP, et al: Azacitidine for the treatment of relapsed and refractory AML in older patients. Leuk Res 39: 124-130, 2015.

9. Rashidi A and Cashen AF: A cytogenetic model predicts relapse risk and survival in patients with acute myeloid leukemia undergoing hematopoietic stem cell transplantation in morphologic complete remission. Leuk Res 39: 77-81, 2015.

10. Martelli MF, Di Ianni M, Ruggeri L, Falzetti F, Carotti A, Terenzi A, Pierini A, Massei MS, Amico L, Urbani E, et al: HLA-haploidentical transplantation with regulatory and conventional T-cell adoptive immunotherapy prevents acute leukemia relapse. Blood 124: 638-644, 2014

11. Byrd JC, Mrozek K, Dodge RK, Carroll AJ, Edwards CG, Arthur DC, Pettenati MJ, Patil SR, Rao KW, Watson MS, et al; Cancer and Leukemia Group B (CALGB 8461): Pretreatment cytogenetic abnormalities are predictive of induction success, cumulative incidence of relapse, and overall survival in adult patients with de novo acute myeloid leukemia: Results from Cancer and Leukemia Group B (CALGB 8461). Blood 100: 4325-4336, 2002.

12. Thakkar SG, Fu AZ, Sweetenham JW, McIver ZA, Mohan SR, Ramsingh G, Advani AS, Sobecks R, Rybicki L, Kalaycio M and Sekeres MA: Survival and predictors of outcome in patients with acute leukemia admitted to the intensive care unit. Cancer 112: 2233-2240, 2008.

13. Benyo M, Flasko T, Molnar Z, Kerenyi A, Batta Z, Jozsa T and Harsfalvi J: Follow-up of thrombin generation after prostate cancer surgery: Global test for increased hypercoagulability. PLoS One 7: e51299, 2012.

14. Diao D, Zhu K, Wang Z, Cheng Y, Li K, Pei L and Dang C: Prognostic value of the $\mathrm{D}$-dimer test in oesophageal cancer during the perioperative period. J Surg Oncol 108: 34-41, 2013.

15. Kachel P, Trojanowicz B, Sekulla C, Prenzel H, Dralle H and Hoang-Vu C: Phosphorylation of pyruvate kinase M2 and lactate dehydrogenase A by fibroblast growth factor receptor 1 in benign and malignant thyroid tissue. BMC Cancer 15: 140, 2015.

16. Park HY, Suh GY, Jeon K, Koh WJ, Chung MP, Kim H, Kwon OJ, Kim K, Jang JH, Jung CW, et al: Outcome and prognostic factors of patients with acute leukemia admitted to the intensive care unit for septic shock. Leuk Lymphoma 49: 1929-1934, 2008.

17. Bennett JM, Catovsky D, Daniel MT, Flandrin G, Galton DA, Gralnick HR and Sultan C: Criteria for the diagnosis of acute leukemia of megakaryocyte lineage (M7). A report of the French-American-British Cooperative Group. Ann Int Med 103: 460-462, 1985.

18. Vardiman JW, Thiele J, Arber DA, Brunning RD, Borowitz MJ, Porwit A, Harris NL, Le Beau MM, Hellström-Lindberg E, Tefferi A and Bloomfield CD: The 2008 revision of the World Health Organization (WHO) classification of myeloid neoplasms and acute leukemia: Rationale and important changes. Blood 114: 937-951, 2009.

19. Danese E, Montagnana M, Cervellin G and Lippi G: Hypercoagulability, D-dimer and atrial fibrillation: An overview of biological and clinical evidence. Ann Med 46: 364-371, 2014 
20. Lee K, Kim JE, Kwon J, Kim I, Yoon SS, Park S, Han KS and Kim HK: Poor prognosis of hypocoagulability assessed by thrombin generation assay in disseminated intravascular coagulation. Blood Coagul Fibrinolysis 25: 241-247, 2014.

21. Sartori M, Migliaccio L, Favaretto E, Cini M, Legnani C, Palareti G and Cosmi B: D-dimer for the diagnosis of upper extremity deep and superficial venous thrombosis. Thromb Res 135: 673-678, 2015.

22. van der Hulle T, Tan M, den Exter PL, Mol GC, Iglesias del Sol A, van de Ree MA, Huisman MV and Klok FA: Selective D-dimer testing for the diagnosis of acute deep vein thrombosis: A validation study. J Thromb Haemost 11: 2184-2186, 2013.

23. Yoon CW, Kim SJ, Bang OY, Chung CS, Lee KH and Kim GM: Premorbid warfarin use and lower D-dimer levels are associated with a spontaneous early improvement in an atrial fibrillation-related stroke. J Thromb Haemost 10: 2394-2396, 2012.

24. Sartori M, Cosmi B, Legnani C, Favaretto E, Valdré L, Guazzaloca G, Rodorigo G, Cini M and Palareti G: The Wells rule and $\mathrm{D}$-dimer for the diagnosis of isolated distal deep vein thrombosis. J Thromb Haemost 10: 2264-2269, 2012.

25. Han X, Sheng X, Jones HM, Jackson AL, Kilgore J, Stine JE, Schointuch MN, Zhou C and Bae-Jump VL: Evaluation of the anti-tumor effects of lactate dehydrogenase inhibitor galloflavin in endometrial cancer cells. J Hematol Oncol 8: 2, 2015

26. Augoff K, Hryniewicz-Jankowska A and Tabola R: Lactate dehydrogenase 5: An old friend and a new hope in the war on cancer. Cancer Lett 358: 1-7, 2015.

27. Dowling P, Pollard D, Larkin A, Henry M, Meleady P, Gately K, O'Byrne K, Barr MP, Lynch V, Ballot J, et al: Abnormal levels of heterogeneous nuclear ribonucleoprotein A2B1 (hnRNPA2B1) in tumour tissue and blood samples from patients diagnosed with lung cancer. Mol Biosyst 11: 743-752, 2015.

28. Choudhry A and DeLoughery TG: Bleeding and thrombosis in acute promyelocytic leukemia. Am J Hematol 87: 596-603, 2012.

29. Chang H, Kuo MC, Shih LY, Dunn P, Wang PN, Wu JH, Lin TL, Hung YS and Tang TC: Clinical bleeding events and laboratory coagulation profiles in acute promyelocytic leukemia. Eur J Haematol 88: 321-328, 2012.

30. Asakura $H$, Takahashi $H$, Tsuji $H$, Matsushita T, Ninomiya $H$, Honda G, Mimuro J, Eguchi Y, Kitajima I and Sakata Y: Post-marketing surveillance of thrombomodulin alfa, a novel treatment of disseminated intravascular coagulation-safety and efficacy in 1,032 patients with hematologic malignancy. Thromb Res 133: 364-370, 2014

31. Mego M, Zuo Z, Gao H, Cohen EN, Giordano A, Tin S, Anfossi S, Jackson S, Woodward W, Ueno NT, et al: Circulating tumour cells are linked to plasma D-dimer levels in patients with metastatic breast cancer. Thromb Haemost 113: 593-598, 2015.

32. Gomes M and Khorana AA: Risk assessment for thrombosis in cancer. Semin Thromb Hemost 40: 319-324, 2014.

33. Yanada M, Matsushita T, Suzuki M, Kiyoi H, Yamamoto K, Kinoshita T, Kojima T, Saito H and Naoe T: Disseminated intravascular coagulation in acute leukemia: Clinical and laboratory features at presentation. Eur J Haematol 77: 282-287, 2006

34. Hess EP and Sztajnkrycer MD: Images in emergency medicine Acute leukemia with blast crisis, disseminated intravascular coagulation, and intraparenchymal hemorrhage. Ann Emerg Med 46: 314, 322, 2005.

35. Tanaka $\mathrm{M}$ and Yamanishi $\mathrm{H}$ : The expression of tissue factor antigen and activity on the surface of leukemic cells. Leuk Res 17: 103-111, 1993.

36. Jácomo RH, Santana-Lemos BA, Lima AS, Assis PA, Lange AP, Figueiredo-Pontes LL, Oliveira LO, Bassi SC, Benício MT, Baggio MS, et al: Methionine-induced hyperhomocysteinemia reverts fibrinolytic pathway activation in a murine model of acute promyelocytic leukemia. Blood 120: 207-213, 2012.

37. Marchetti M, Russo L, Balducci D and Falanga A: All trans-retinoic acid modulates the procoagulant activity of human breast cancer cells. Thromb Res 128: 368-374, 2011.
38. Marchetti M, Diani E, ten Cate $\mathrm{H}$ and Falanga A: Characterization of the thrombin generation potential of leukemic and solid tumor cells by calibrated automated thrombography. Haematologica 97: 1173-1180, 2012.

39. Ohkawara H, Ishibashi T, Sugimoto K, Ikeda K, Ogawa K and Takeishi Y: Membrane type 1-matrix metalloproteinase/Akt signaling axis modulates TNF- $\alpha$-induced procoagulant activity and apoptosis in endothelial cells. PLoS One 9: e105697, 2014.

40. Poovassery JS, Sarr D, Smith G, Nagy T and Moore JM: Malaria-induced murine pregnancy failure: Distinct roles for IFN-gamma and TNF. J Immunol 183: 5342-5349, 2009.

41. de Menezes YA, Félix-Silva J, da Silva-Júnior AA, Rebecchi IM, de Oliveira AS, Uchoa AF and Fernandes-Pedrosa Mde F: Protein-rich fraction of Cnidoscolus urens (L.) Arthur leaves: Enzymatic characterization and procoagulant and fibrinogenolytic activities. Molecules 19: 3552-3569, 2014.

42. Gansler J, Preissner KT and Fischer S: Influence of proinflammatory stimuli on the expression of vascular ribonuclease 1 in endothelial cells. FASEB J 28: 752-760, 2014.

43. Zucker S, Mirza H, Conner CE, Lorenz AF, Drews MH, Bahou WF and Jesty J: Vascular endothelial growth factor induces tissue factor and matrix metalloproteinase production in endothelial cells: Conversion of prothrombin to thrombin results in progelatinase A activation and cell proliferation. Int J Cancer 75: 780-786, 1998.

44. Hawiger J, Veach RA, Liu XY, Timmons S and Ballard DW IkappaB kinase complex is an intracellular target for endotoxic lipopolysaccharide in human monocytic cells. Blood 94: 1711-1716, 1999

45. Ma J, Duffy MR, Deng L, Dakin RS, Uil T, Custers J, Kelly SM, McVey JH, Nicklin SA and Baker AH: Manipulating adenovirus hexon hypervariable loops dictates immune neutralisation and coagulation factor $\mathrm{X}$-dependent cell interaction in vitro and in vivo. PLoS Pathog 11: e1004673, 2015.

46. Velasco F, Torres A, Rojas R, Alvarez MA, Gomez P and Castillo D: Increase in the D-dimer levels during treatment in patients with acute myelogenous leukemia. Haemostasis 22: 117-123, 1992.

47. Cortelazzo S, Ponzoni M, Ferreri AJ and Hoelzer D: Lymphoblastic lymphoma. Crit Rev Oncol Hematol 79: 330-343, 2011.

48. Rao D, Ghalaut VS, Ghalaut PS and Rao S: Case series: CSF LDH, proteins and electrolyte levels in patients of acute lymphocytic leukemia. Clin Chim Acta 413: 1045-1048, 2012.

49. Thomas X, Danaïla C, Le QH, Sebban C, Troncy J, Charrin C, Lhéritier V, Michallet M, Magaud JP and Fiere D: Long-term follow-up of patients with newly diagnosed adult acute lymphoblastic leukemia: A single institution experience of 378 consecutive patients over a 21 -year period. Leukemia 15 : 1811-1822, 2001

50. Yeh CH, Tseng R, Hannah A, Estrov Z, Estey E, Kantarjian $H$ and Albitar M: Clinical correlation of circulating heat shock protein 70 in acute leukemia. Leuk Res 34: 605-609, 2010.

51. Suvajdžić N, Cvetković Z, Dorđević V, Kraguljac-Kurtović N, Stanisavljević D, Bogdanović A, Djunić I, Colović N, Vidović A, Elezović I and Tomin D: Prognostic factors for therapy-related acute myeloid leukaemia (t-AML)-a single centre experience. Biomed Pharmacother 66: 285-292, 2012.

52. Litzow MR, Othus M, Cripe LD, Gore SD, Lazarus HM, Lee SJ, Bennett JM, Paietta EM, Dewald GW, Rowe JM, et al: Failure of three novel regimens to improve outcome for patients with relapsed or refractory acute myeloid leukaemia: A report from the Eastern Cooperative Oncology Group. Br J Haematol 148: 217-225, 2010.

53. Shiozawa Y, Takita J, Kato M, Sotomatsu M, Koh K, Ida K and Hayashi Y: Prognostic significance of leukopenia in childhood acute lymphoblastic leukemia. Oncol Lett 7: 1169-1174, 2014.

54. Hossain MJ, Xie L and Caywood EH: Prognostic factors of childhood and adolescent acute myeloid leukemia (AML) survival: Evidence from four decades of US population data. Cancer Epidemiol 39: 720-726, 2015. 